\title{
Reliability evaluation of buck converter based on thermal analysis
}

\author{
Mohammad Mojibi, Mahdi Radmehr
}

Electrical Engineering Department, Islamic Azad University, Sari branch, Iran

\begin{abstract}
The design, which is based on the concept of reliability, is impressive. In power electronic circuits, the reliability design has been shown to be useful over time. Moreover, power loss in switches and diodes plays a permanent role in reliability assessment. This paper presents a reliability evaluation for a buck converter based on thermal analysis of an insulated-gate bipolar transistor (IGBT) and a diode. The provided thermal analysis is used to determine the switch and diode junction temperature. In this study, the effects of switching frequency and duty cycle are considered as criteria for reliability. A limit of $150^{\circ} \mathrm{C}$ has been set for over-temperature issues. The simulation of a $12 \mathrm{~kW}$ buck converter (duty cycle $=42 \%$ and switching frequency $=10 \mathrm{kHz}$ ) illustrates that the switch and diode junction temperature are $117.29^{\circ} \mathrm{C}$ and $122.27^{\circ} \mathrm{C}$, respectively. The results show that mean time to failure for the buck converter is 32,973 hours.
\end{abstract}

Keywords: Reliability; Mean time to failure; Buck converter; Junction temperature.

\section{Ocena zanesljivosti buck pretvornika na osnovi termične analize}

\begin{abstract}
Izvleček: $\vee$ prispevku je predstavljena ocena zanesljivosti buck pretvornika na osnovi termične analize bipolarnega tranzostorja z izoliranimi vrati (IGBT) in diode. Termična analiza je uporabljena za določitev temperature spoja diode in stikala. Kriterij zanesljivosti je vpliv frekvence preklopa in obratovalnega cikla. Zgornja temperaturna meja je $150^{\circ} \mathrm{C}$. Simulacije $12 \mathrm{~kW}$ buck pretvornika (obratovalni cikel $=41 \%$, frekvenca preklopa $=10 \mathrm{kHz}$ ) pokažejo temperaturo stikala $117.29^{\circ} \mathrm{C}$ in spoja diode $122.27^{\circ} \mathrm{C}$. Povprečen pričakovani čas do okvare je 32,973 ur.
\end{abstract}

Ključne besede: zanesljivost; srednji čas do okvare; buck pretvornik; temperatura spoja.

* Corresponding Author's e-mail: radmehr@iausari.ac.ir

\section{Introduction}

In recent years, the use of renewable energy has become more popular because of the negative impacts of fossil fuels and the environmental pollution they cause. Nowadays, various methods and topologies for extracting energy from different renewable sources are being introduced. Solar energy, which can be harnessed using photovoltaic panels, is one of the alternative sources of energy and offers many advantages (such as less negative environmental effects and affordability) in comparison with other sources. As renewable energy sources continue to be used more often, more attention is now being paid to power electronics. A converter frequently used for photovoltaic panels in power electronics, as well as in several wind turbine energy conversion systems, is the $\mathrm{dc}$-dc converter. In the last few decades, there have been many dc-dc converter topologies introduced, which have been generally classified based on the ratio of voltage output to input (also known as gain) into three fundamental groups: buck, boost, and buckboost. This paper focuses on the buck converter type, often used in small or low power systems as a simple, remarkably efficient way to reduce the input voltage to a regulated dc voltage [1].

More efficient use of any device has always been a goal of manufacturers. In power electronics, the proper functioning of converters encompasses high output quality, a long lifespan, and less energy consumption. Due to the increase of power electronic converters in different devices, an especially important factor for optimizing converters is power quality, which can be described in terms of its thermal characteristics. Indeed, 
previous researches have clarified the relationship of converter performance and quality in terms of heat loss [2-4]. Furthermore, Usui and Ishiko presented a simple approach for the thermal design of an IGBT module practised only in steady state operation [5].

In recent decades, different approaches for thermal analysis have also been introduced, including the highly accurate method of computational fluid dynamics (CFD), based upon how airflow conditions determine heat transfer coefficients [6].

Converter lifespan is another significant factor with a direct relationship to reliability, which represents the probability of failure in a system at a specific time [7]. The reliability of a system depends on various parameters; for this reason, identifying the indicators and calculation of the reliability parameters of the system's parts is required. Usually, two parameters are used to assess the reliability of the system. The first parameter is failure rate explained by failure distribution, and the next parameter is mean time to failure (MTTF) which presents the average operation time before the first failure of a component [8].

There are different researches related to the reliability assessment of various circuits and power converters. These circuits include multilevel inverters $[9,10], D C$ DC converters [11], and AC-AC converters [12].

Khosroshahi et al. [13] evaluated the reliability of two conventional and interleaved DC-DC boost converters based on the MIL-HDBK-217 procedure. They found that the interleaved boost converter performs better in terms of reliability in comparison with the conventional boost converter. Perhaps, the most crucial weakness of this article is using approximate relations for calculating power dissipation in the switch and diode, which are based on their internal resistances.

Rashidi-Rad et al. [14] performed a reliability analysis of modular multilevel converters (MMCs) with the presence of half and full-bridge cells. Their examination illustrated that the modular converters that used half-bridge cells have more reliable performance than other state.

Arifujjaman and Chang [12] compared the reliability of three ac-ac converter namely intermediate boost converter (IBC), intermediate buck-boost converter $(\mathrm{IBBC})$, and back-to-back converter (BBC) with the well-known matrix converter. They concluded that the intermediate boost converter exhibits more reliable than other ones.

In [15], the reliability of a buck converter was assessed in the presence of $\mathrm{N}$-channel and P-channel MOSFET drivers. They showed that the considered buck converter has more reliability when an $\mathrm{N}$-channel MOSFET is used as switch. However, they ignored some portions of the power losses in switch and diode, thus the obtained results may not be referred.

Ranjbar et al. [16] carried out a reliability assessment of single/two stage power factor correction (PFC) converters. The MIL-HDBL-217 was considered as reliability estimation procedure in this analysis. The outcomes demonstrated that the lifespan of a singlestage converter is about 1.6 times longer than the two-stage converter. In this study, for simplicity of calculations, the case temperature was intended to be a fix value of $35^{\circ} \mathrm{C}$. This leads to an inaccuracy in the results.

The main purpose of this paper is to estimate the reliability of a buck converter based on the MILHDBK-217 standard. Although this standard has been criticized for being obsolete, it is still extensively used in military and aerospace industries to provide a basis for comparison between two or more different circuits [17]. For this reason, several previous literatures have employed this standard for predicting the reliability of power electronic converters (e.g., [1822]). To investigate the reliability of semiconductor devices, there is a need for determining the junction temperature in these types of components, and in this study, the selected approach is based on information from manufacturer's datasheet. A one-cell Cauer thermal model was utilized in order to provide a precise relationship between the power losses and the junction temperatures in the presence of a heatsink. This approach has an acceptable result as well as suitable speed in calculations. Additionally, this is the first time that the simultaneous impact of switching frequency and duty cycle on the power losses and the junction temperature has been analyzed.

The rest of this paper is structured as follows: Section 2 describes the buck converter as a case study. The reliability principals employed for the analysis are discussed in Section 3. In Section 4, the accurate thermal analysis for the buck converter is discussed. In Section 5, the results and reliability evaluation are presented. Finally, conclusions are drawn in Section 6.

\section{The buck converter}

The buck converter circuit shown in Figure 1 is a highly efficient step-down dc-dc converter which is commonly used in switched-mode power supply circuits (SMPS). Generally, the dc input voltage of the buck converter 
is derived from the output of a rectifier through a dclink. In this paper, an IGBT is used as a switch for the converter. Also, the thermal analysis has been performed considering the effect of temperature on the voltage drop between the collector and emitter junctions of the diode and the transistor, because practically this voltage should be estimated by the means of both collector current and temperature, $V_{C E}\left(i_{C} T_{j}\right)$.

The voltage drop for an IGBT can be experimentally measured by sensing the current of switch. Typically, a low-ohmic resistor is placed between the ground and emitter, and by flowing the current through this sensing resistor, the occurred voltage drop can be identified by another monitoring circuit. An improved sensing method is based on four external connection nodes for finding $\mathrm{R}_{\mathrm{DS}}(\mathrm{on})$ of the switching power MOSFET, or $\mathrm{V}_{\mathrm{CE}}$ (on) of an IGBT. The drawback of these methods is need for protection circuits and expensive discrete components against high voltage [23]. But, the employed approach in this paper will provide us the opportunity to identify the voltage drop indirectly.

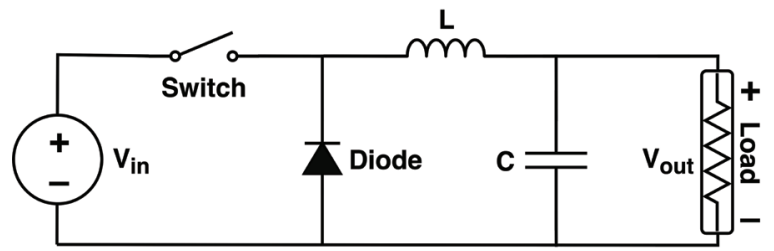

Figure 1: Topology of a buck DC-DC converter.

When the buck converter operates in continuous conduction mode (CCM), the current through the inductor $\left(I_{L}\right)$ will never fall to zero during the cycle. Assuming the steady state operation for this converter, it can be concluded that the energy stored in each of circuit components at the end of a cycle is equal to energy stored at the beginning of the cycle. Therefore, the input and output voltages in the buck converter have a direct relationship with the duty cycle of the pulses, which can be shown as follows:

$$
V_{\text {out }}=D V_{\text {in }}
$$

where $V_{\text {out }}, V_{\text {in }}$ and $D$ are the output voltage, the input voltage, and the converter duty cycle, respectively. With regard to the value of $0<D<1$, as a consequence, the output voltage is always lower than the input voltage. The basic characteristics of the converter are summarized in Table 1.
Table 1: Rated parameters for the desired buck converter.

\begin{tabular}{|l|l|}
\hline Characteristic & Value \\
\hline Rated output active power Po & $12 \mathrm{~kW}$ \\
\hline Input voltage Vin & $300 \mathrm{~V} \mathrm{DC}$ \\
\hline Output voltage Vout & $125 \mathrm{~V} \mathrm{DC} \pm 1.2 \%$ \\
\hline Switching frequency fs & $10 \mathrm{kHz}$ \\
\hline Inductor L & $3 \mathrm{mH}$ \\
\hline Capacitor C & $1 \mu \mathrm{F}$ \\
\hline
\end{tabular}

A buck converter with parameters based upon Table 1 is simulated in MATLAB/Simulink. An open-loop controller is used for the simulation. Furthermore, a value of $42 \%$ is considered the duty cycle in this state. The results of the simulation are shown in Figure 2:

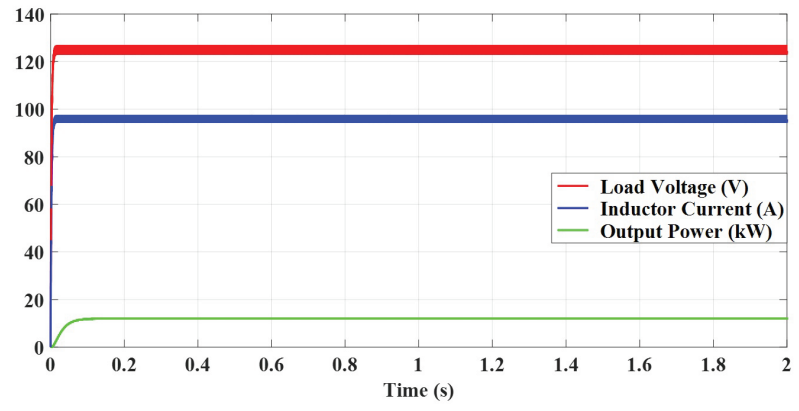

Figure 2: The simulation results of basic characteristics of the converter.

\section{The reliability principle}

Reliability means the ability of an item to perform a specific function under given conditions over a specific time period, which is expressed as a probability or failure frequency [24]. The importance of reliability in space and in the arms industry is more prominent than that of other industries because in these significant instruments, detecting or replacing a failed part is very difficult. Different methods have been introduced to improve the reliability of a system. One of these methods involves adding redundancy to parts of the converters, thereby increasing the global reliability of a system. Reliability is improved by adding more parts for redundancy, but cost is a deterrent to increasing the number of redundancy circuits [25].

One of the factors influencing reliability is failure rate. Failure rate can be expressed as the probability of failure per unit time occurring in the interval $[t, t+\Delta t]$, and there is no failure before time $t$. Usually, $\Delta t$ is a very small value, and it is close to zero [26]. 
If we present a failure rate with $\lambda$, the probability distribution function for failure can be expressed as a relationship in terms of failure rate, and can be obtained using the exponential distribution. Equation (2) presents the distribution function:

$$
f(t, \lambda)=\lambda e^{-\lambda t}
$$

Also, the reliability function can be expressed as follows [8]:

$$
R(t, \lambda)=e^{-\lambda t}
$$

where in the above equations, $\lambda$ is the component's failure rate. Another influential factor of reliability is mean time to failure (MTTF). MTTF is the average length of time before the first failure of a component or device occurs after it starts to work, after which the device is no longer able to continue with its normal operation. MTTF is expressed by the integral of reliability as follows:

$$
M T T F=\int_{0}^{+\infty} R(t) d t
$$

A simple equation for the expression of MTTF is derived by substituting Equation (3) with Equation (4):

$$
M T T F=\frac{1}{\lambda}
$$

In the last decades, various procedures have been introduced by different organizations to estimate the reliability. Some of the most popular procedures, such as RAC's PRISM [27], Telcordia SR-332 [28], SAE's PREL [29], CNET's reliability prediction method [30], Siemens SN29500 standard [31] and British Telecom's HRD-4 [32], are described and discussed according to the organization's strategies. A comprehensive comparison has been made among these procedures in [33]. Today, the MIL-HDBK-217F handbook is used as a suitable reference for estimating reliability. This paper also used a calculation based on the MIL-HDBK-217F procedure [34].

Two methods that include parts stress and parts count are discussed in the handbook. In the parts count method, less information is required, such as number of parts, quality level and environmental situation [35].

According to the series structure of the buck converter, the failure rate can be calculated using the summation of all failure rates of the circuit components, as shown in Equation (6) [36]: $\lambda_{\text {System }}=\sum \lambda_{\text {Components }}$

where $\lambda_{\text {components }}$ is the failure rate of each circuit component.

With the increasing complexity of the studied system, the overall system should be divided into subsystems so that the reliability evaluation becomes simpler and more concise [37].

\subsection{The Reliability of Components}

The buck converter consists of various components, including switch, diode, inductor and controller. In related studies on the reliability of electronic components (switches, diodes, capacitors and inductors), specific relationships for determining the failure rate for each component are expressed as follows $[25,34,35,38]$ :

$$
\begin{aligned}
& \lambda_{p}(\text { Capacitor })=\lambda_{b} \pi_{C V} \pi_{Q} \pi_{E} \\
& \lambda_{p}(\text { Inductor }- \text { Transformer })=\lambda_{b} \pi_{C} \pi_{Q} \pi_{E} \\
& \lambda_{p}(\text { Switch })=\lambda_{b} \pi_{T} \pi_{A} \pi_{R} \pi_{S} \pi_{Q} \pi_{E} \\
& \lambda_{p}(\text { Diode })=\lambda_{b} \pi_{T} \pi_{C} \pi_{S} \pi_{Q} \pi_{E}
\end{aligned}
$$

In Equations (7)-(10), $\lambda_{b}$ is the base failure rate, which is different for each component. Additionally, $\pi$ is pi factor related to each component, and should be determined accurately. The controller failure rate can be considered 0.88 (failures $/ 10^{6} \mathrm{~h}$ ) [35].

Due to the sudden progress of IGBTs, field data and reliability model related to this component are not available. Furthermore, one drawback of the employed standard is the lack of relationships for estimating the reliability of IGBT devices, because the latest update of the standard was before the comprehensive introduction of this kind of switch. In prior studies, some researchers preferred to use MOSFET equations for calculating IGBT failure rate [37], and alternatively, several papers claimed that using the reliability formulas of bipolar power transistors instead of IGBT would provide appropriate results [38]. In this paper, it is assumed that the IGBT modules have the same factors of high-power bipolar transistors. Another assumption is the fact that the value of base failure for an IGBT can be easily obtained by knowing the module's field data, and according to [38], its value for a medium-power IGBT is equal to $100 \mathrm{FIT}\left(\lambda_{b(S)}=0.1\right.$ failures $\left./ 10^{6} \mathrm{~h}\right)$. 
The factors $\pi_{O}$ and $\pi_{E^{\prime}}$ represent quality and environmental, respectively. The quality and environmental factor values can be assumed to be equal to one, although the effects of these two factors were eliminated [25]. Another factor is the application factor, $\pi_{A^{\prime}}$ and for switching application is equal to 0.7. The power rating factor, $\pi_{R^{\prime}}$ is directly related to the rated power which is equal to 10 for a 500 W IGBT module. The voltage stress factor for IGBT $\left(\pi_{S(S)}\right)$ can be calculated by

$\pi_{S(S)}=0.045 \times \exp \left(3.1 \times V_{S(S)}\right)$

where $V_{S(S)}$ is the ratio of applied collector-emitter voltage to rated voltage.

Diodes are usually used as power rectifiers in power electronic converters. In the industry, the diodes with a reverse recovery rate of 500 nanoseconds or less (approximately 0.1 of standard rectifiers) are categorized as fast rectifiers. If this period is reduced to 100 nanoseconds or less, they will be named as superfast rectifiers [39]. Given that the diodes within the IGBT modules are classified as fast recovery power rectifier, they must be set to the appropriate level according to the standard, and the base failure rate for the diodes will be equal to 0.025 failures $/ 10^{6} \mathrm{~h}$.

In the following equation, $\pi_{S(D)}$ is the stress factor for diodes:

$\pi_{S}=\left(V_{S(D)}\right)^{2.43}$

where $V_{S(D)}$ is the ratio of operating voltage to nominal voltage.

$\pi_{C}$ explains the contact construction. Considering it is metallurgically bonded, the contact construction leads to the value of 1 for $\pi_{C}$ [35].

In the capacitor failure rate, $\pi_{C V}$ is the capacitor factor which can be calculated as follows:

$\pi_{C V}=0.34 \times C^{0.12}$

where $C$ is the capacitance in microfarad.

The inductor base failure rate can be expressed as follows:

$$
\lambda_{b(L)}=0.000335 \times \exp \left(\frac{T_{H S}+273}{329}\right)^{15.6}
$$

where $T_{H S}$ is the hot spot temperature in degree Celsius, which can be determined using Equation (15):

$$
T_{H S}=T_{A}+1.1 \times \Delta T
$$

In Equation (15), $T_{A}$ expresses the device ambient operating temperature in degree Celsius. Also, $\Delta T$ is the average temperature rise above the ambient [34, 35]. The inductor failure rate is much lower than other circuit components, so it can be omitted from the analysis.

The capacitor failure rate can be described by the following equation:

$$
\lambda_{b(C)}=0.00254\left[\left(\frac{S}{0.5}\right)^{3}+1\right] \exp \left(5.09 \times\left(\frac{T_{A}+273}{378}\right)^{5}\right)
$$

where $S$ is the ratio of operating voltage to nominal voltage.

$\pi_{T}$ is the temperature factor that, for the switch and diode, can be expressed as follows [35]:

$$
\begin{aligned}
& \pi_{T(S)}=\exp \left(-2114 \times\left(\frac{1}{T_{j}+273}-\frac{1}{298}\right)\right) \\
& \pi_{T(D)}=\exp \left(-3091 \times\left(\frac{1}{T_{j}+273}-\frac{1}{298}\right)\right)
\end{aligned}
$$

where $T_{j}$ is the junction temperature.

One of the major concerns regarding reliable power electronics is the operating temperature. Thus, it seems that the precise determination of the junction temperature results in a more accurate analysis of the reliability. There are five different approaches introduced by Reliability Analysis Center (RAC) to predict the junction temperature for semiconductor devices. In this study, Method IV was used. This method is utilized when a heatsink is mounted on the device, and the exact value of the case temperature is also available [40].

According to the used approach, the junction temperature can be calculated from Equation (19):

$T_{j}=T_{C}+\theta_{j c} \times P_{l o s s}$

In Equation (19), $T_{c}$ is the heat sink temperature, $\theta_{j c}$ is the thermal resistance of the diode or switch, and $P_{\text {loss }}^{j c}$ is the total power losses of switch or diode. 
In fact, Equation (19) exhibits a scheme of the one-cell Cauer thermal network. Figure 3 shows this modeling.

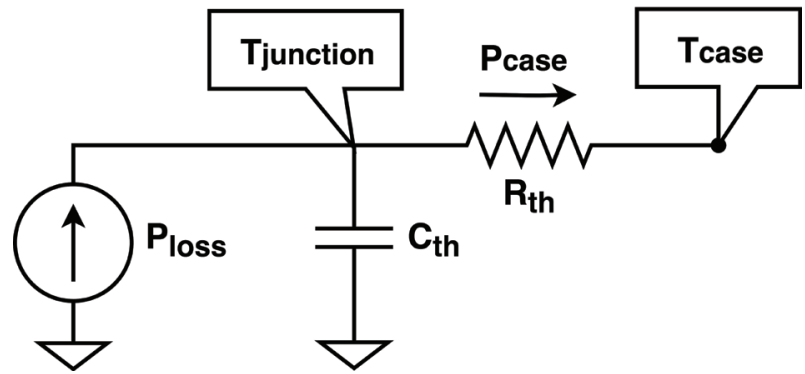

Figure 3: One-cell Cauer thermal network model.

In Figure $3, R_{\text {th }}$ and $C_{\text {th }}$ are the thermal resistance and capacitance from junction-to-case, respectively, and these indicators should be selected from the datasheet of the used IGBT module (both diode and IGBT). Also, by similarity of thermal modeling and electrical modeling, the junction temperature can be found easily from the total power losses.

Foster and Cauer thermal network models are commonly used for dynamic thermal modeling, and both models use thermal resistance $(R)$ and thermal capacitance $(C)$, which are joined together as ladders and form multiple layers. Although many manufacturers of power modules typically offer the Foster model limited to four layers [41], the others only provide the transient thermal impedance curve $\left(Z_{t h}\right)$ within the datasheet; and the values for each layer should be obtained by curve fitting tools $[42,43]$ or algorithms [44]. Here, the particle swarm optimization (PSO) algorithm was used [45] to identify four RCs related to the four different layers.

Due to the need for a high number of simulations in this paper, a one-layer Cauer model has been employed for thermal analysis between junction and case. In addition to having the suitable precision, this model improves the simulation speed significantly. One issue for modeling thermal networks is the conversion of a Foster model to a Cauer model, and vice versa (for more details about these two thermal networks, refer to [46]). Considering that the four-layer Foster model is a four-order system, a circuit software is required to convert it to the first-order Cauer model. In this study, we used the LTspice software to find the values of $R_{\text {th }}$ and $C_{t h}$ for the one-cell thermal model. The resistance of the single-layer model is equal to the sum of the four resistances of the four-layer model, which is the same as the peak of the thermal impedance curve. In order to determine the value of capacitance, a curve fitting on the outputs of the LTspice software was performed. Thus, the obtained values of the thermal resistance and capacitance for the Cauer network are $0.25 \mathrm{~K} / \mathrm{W}$ and
$0.18 \mathrm{~J} / \mathrm{K}$, respectively. Similarly, the extracted values for the diode are $0.46 \mathrm{~K} / \mathrm{W}$ and $0.1 \mathrm{~J} / \mathrm{K}$, respectively.

To complete the thermal model, the heat transfer from the case to the ambient through the heatsink should also be added. Modeling of this part is shown in Figure 4.

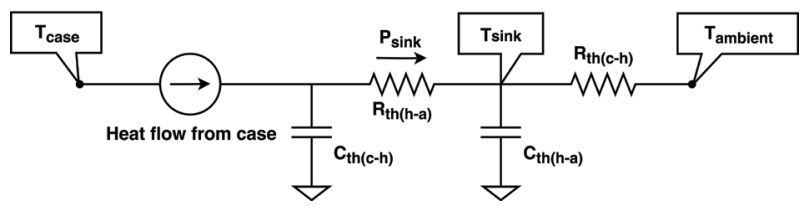

Figure 4: Thermal modeling from case-to-ambient.

In order to implement this part, the thermal and physical elements of MATLAB/Simulink have been used. The case-heatsink thermal resistance value $\left(R_{\text {th(-h) }}\right)$ is driven from the datasheet, and is equal to $0.05 \mathrm{~K} / \mathrm{W}$ for the module under study. A 10-inch aluminum heatsink manufactured by the Wakefield-Vette under forced air cooling ( 500 feet per minute) is considered as the cooling system. According to the described circumstances, the value of $R_{\text {thh-a) }}$ will be equal to approximately $0.1 \mathrm{~K} / \mathrm{W}$. For simplicity, we consider the case-heatsink thermal capacitance to be $0.25 \mathrm{~J} / \mathrm{K}$. The heatsink thermal capacitor is also assumed to be $0.01 \mathrm{~J} / \mathrm{K}$, based on [47].

Finally, as mentioned earlier, the determination of semiconductors' failure rate depends on their power losses. The utilized approach in this paper is based on calculating both conduction and switching losses for the diode and switch using lookup tables. Detailed explanation of this process is given in [48].

\section{Thermal analysis of buck converter}

In order to determine the thermal analysis of the converter, a Fuji 2MBI150U2A-060 600V/150A IGBT module is selected as the switch. The features of this module include high speed switching, voltage drive, and low inductance [49].

Figure 5 shows the IGBT on-state characteristics in $25^{\circ} \mathrm{C}$ and $125^{\circ} \mathrm{C}$, based on Collector current versus CollectorEmitter voltage.

The rated current distributions for the switch and diode are shown is Figure 6, which this figure clearly demonstrates the summation of switch and diode currents can produce the inductor current (when the switch is on, the diode is off). Conversely, when the diode is on, the switch is off. The inductor current will be a triangular waveform when its voltage analogue is pulsating in a rectangular form 


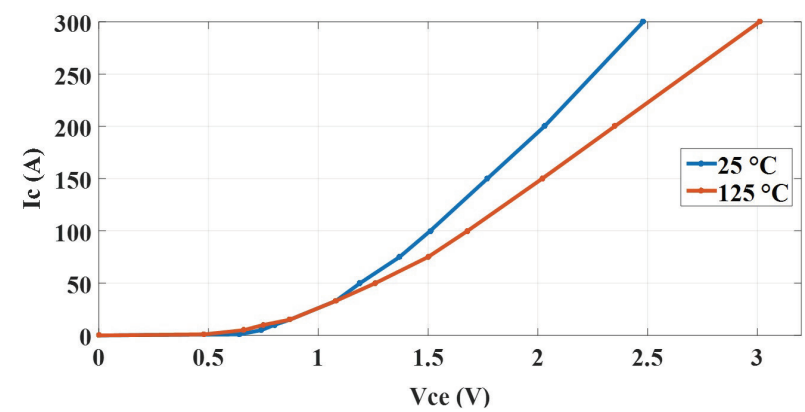

Figure 5: IGBT's Collector current in terms of CollectorEmitter voltage [49].

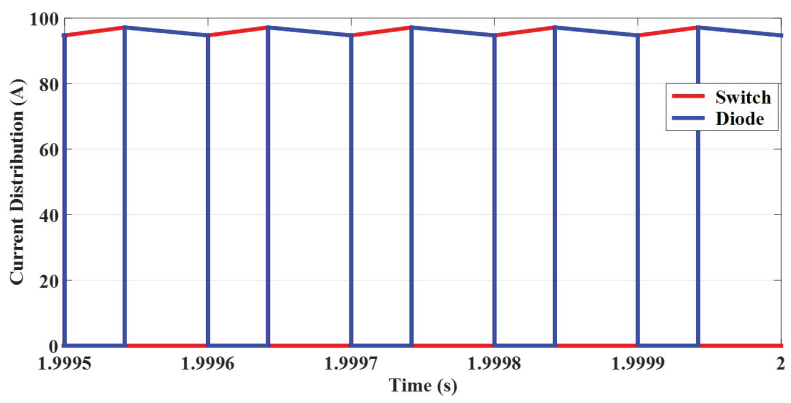

Figure 6: Current distributions of the switch and diode.

(a)

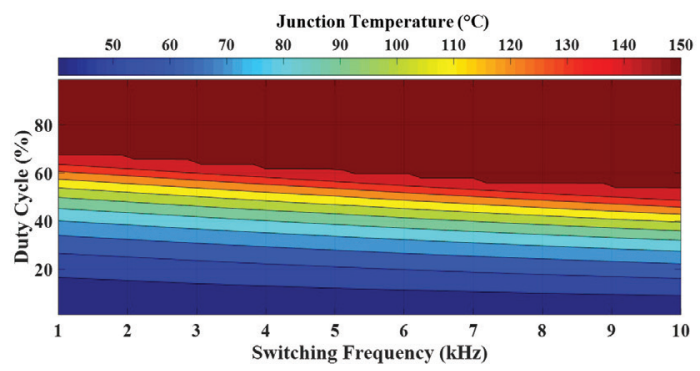

(b)

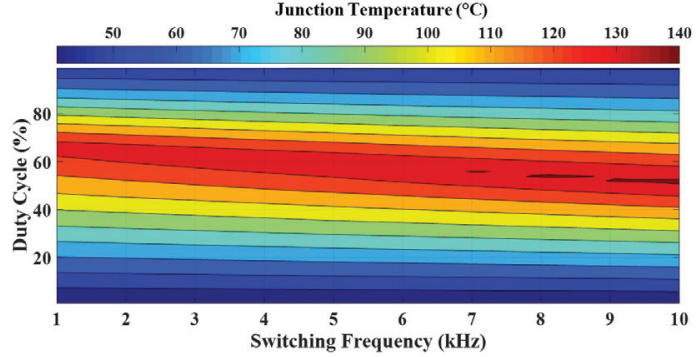

(c)

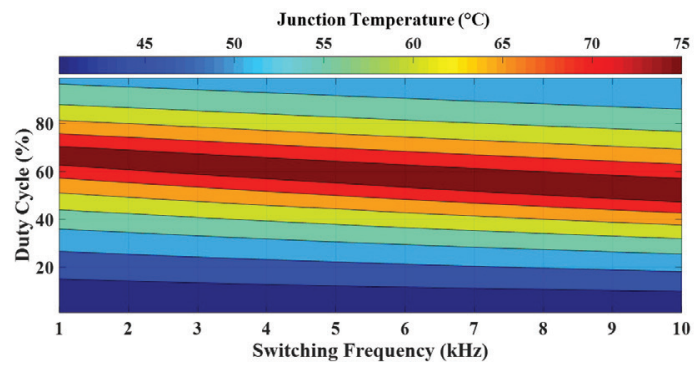

Figure 7: 2D plots for showing effects of duty cycle and switching frequency on (a) the switch junction temperature, (b) the diode junction temperature, (c) the heat sink temperature.
The most important factor in the evaluating converter reliability is temperature, which is directly related to power losses of the switch and diode. Thus, the calculation of the junction temperature is a sure way to assess reliability. Various elements can influence the junction temperature and its value will change with variations in component's power losses; increasing the switching frequency can lead to more power losses in the switch and diode. Another important factor for power losses in the buck converter is the modulation index or duty cycle. By setting a different duty cycle for the converter, the gain of the output voltage will change. An analysis is undertaken to show the effects of the switching frequency and the duty cycle on the junction temperature and the heat sink temperature. Figures 7 and 8 represent the items that can affect temperatures in the form of two-dimensional and three-dimensional diagrams.

(a)

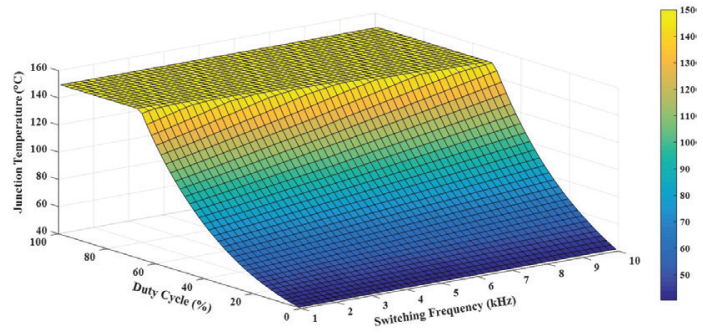

(b)

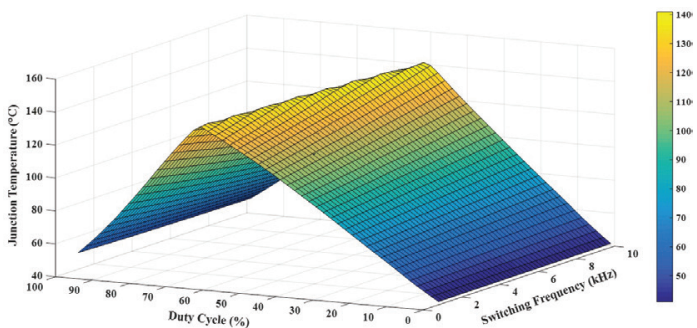

(c)

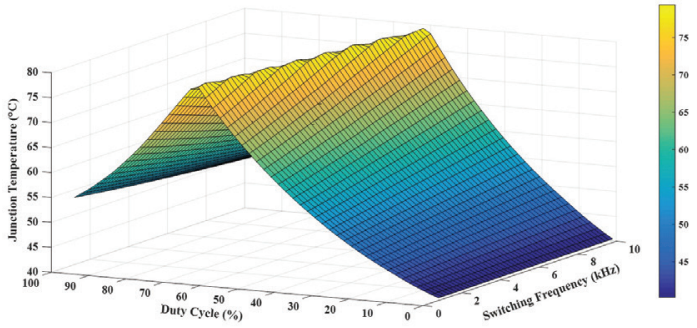

Figure 8: 3D plots for showing effects of duty cycle and switching frequency on (a) the switch junction temperature, (b) the diode junction temperature, (c) the heat sink temperature.

It is evident from Figures 7 and 8 that a lower duty cycle corresponds to a better performance in terms of temperature because of the decrease in the output voltage level. Therefore, it is possible to change the duty cycle to its desired value by changing the basic 
characteristics of the converter. Increasing switching frequency from 1 to $10 \mathrm{kHz}$ has a negligible impact on the temperature, but switching frequencies higher than $10 \mathrm{kHz}$ will increase the temperature. The overtemperature is limited to $150^{\circ} \mathrm{C}$, so the converter ceases to operate beyond this temperature. For duty cycles higher than $51 \%$, the junction temperature of the switch rises beyond the over-temperature. This shows the weakness of heatsink for cooling the module under thermal pressure. Using a more efficient heatsink will result in a decrease in the junction temperature and the extension of authorized period for increasing the duty cycle. The calculated power losses for the switch and diode (based on the rated parameters) are $145.02 \mathrm{~W}$ and $89.69 \mathrm{~W}$, respectively. Also, the results illustrate that the switch junction temperature for a duty cycle of $42 \%$ and $f_{s}=10 \mathrm{kHz}$ is $117.29^{\circ} \mathrm{C}$. The junction temperature of the diode is $122.27^{\circ} \mathrm{C}$, and it has a higher value than the switch's temperature.

Although the diode power losses are less than the switch, due to the greater diode thermal resistance in comparison with the switch (0.46 compared to 0.25 $\mathrm{K} / \mathrm{W})$, the diode junction temperature would be higher. This issue can also be deduced from the physical structure of the IGBT module, because the crosssection of the diode chip is smaller than the switch, and with the same heat flux applied to the both chips, the smaller chip will experience higher temperature increase. This shows that greater thermal resistance can produce higher junction temperatures.

Typically, the heat sink temperature is much lower than that at the junction of other components, and in reliability designs, a temperature of $40^{\circ} \mathrm{C}$ is considered a stable value for the temperature of the heat sink [50]. However, the structure and design of the heat sink can affect its operating temperature. The simulation results showed that the heat sink temperature measured with the parameters rated was $69.32^{\circ} \mathrm{C}$.

\section{The reliability evaluation of buck} converter

Estimated failure rates for each component under identical conditions are shown in Tables 2-5. Due to the application of the switch, a value of 0.7 is considered to be the application factor. Values of $\pi_{Q}$ and $\pi_{E}$ were set for the components according to [34].

A value of 0.88 was considered to be the failure rate of the controller, similar to [35], and the failure rate of the converter can be estimated by summing all of the failure rates (we only have one from each component). The failure rate of the entire system was calculated at 30.328 (failures $/ 10^{6} \mathrm{~h}$ ) by the following equation:

$$
\lambda_{\text {System }}=\sum n_{i} \lambda_{i}=\left\{\begin{array}{l}
\lambda_{P(S)}=27.188 \\
\lambda_{P(D)}=2.014 \\
\lambda_{P(C)}=0.197 \\
\lambda_{P(L)}=0.049 \\
\lambda_{P(\text { Controller })=0.88}
\end{array}\right\}+
$$

By reversing the failure rate, MTTF can be calculated as follows:

$$
\text { MTTF }=\frac{1}{\lambda_{\text {System }}}=\frac{10^{6}}{30.328}=32,973 \text { hours }
$$

Table 2: The estimated base failure rate for the switch.

\begin{tabular}{|c|c|c|c|c|c|c|c|c|c|}
\hline $\mathrm{P}_{\text {Loss }}(\mathrm{W})$ & $\mathrm{T}_{\mathrm{j}}\left({ }^{\circ} \mathrm{C}\right)$ & $\pi_{\mathrm{T}}$ & $\pi_{\mathrm{A}}$ & $\Pi_{\mathrm{R}}$ & $\Pi_{\mathrm{S}}$ & $\Pi_{\mathrm{E}}$ & $\Pi_{\mathrm{Q}}$ & $\lambda_{\mathrm{b}}$ & $\lambda_{\mathrm{P}}$ (failures $\left./ 10^{6} \mathrm{~h}\right)$ \\
\hline 145.02 & 117.29 & 5.35 & 0.7 & 10 & 0.22 & 6 & 5.5 & 0.1 & 27.188 \\
\hline
\end{tabular}

Table 3: The estimated base failure rate for the diode.

\begin{tabular}{|c|c|c|c|c|c|c|c|c|}
\hline$P_{\text {Loss }}(\mathrm{W})$ & $\mathrm{T}_{\mathrm{j}}\left({ }^{\circ} \mathrm{C}\right)$ & $\pi_{\mathrm{T}}$ & $\pi_{\mathrm{C}}$ & $\pi_{\mathrm{S}}$ & $\pi_{\mathrm{E}}$ & $\pi_{\mathrm{Q}}$ & $\lambda_{\mathrm{b}}$ & $\lambda_{\mathrm{P}}$ (failures $/ 10^{6} \mathrm{~h}$ ) \\
\hline 89.69 & 122.3 & 12.85 & 1 & 0.19 & 6 & 5.5 & 0.025 & 2.014 \\
\hline
\end{tabular}

Table 4: The estimated base failure rate for the capacitor.

\begin{tabular}{|c|c|c|c|c|c|c|}
\hline Value & $\mathrm{T}_{\mathrm{A}}\left({ }^{\circ} \mathrm{C}\right)$ & $\pi_{\mathrm{CV}}$ & $\pi_{\mathrm{E}}$ & $\pi_{\mathrm{Q}}$ & $\lambda_{\mathrm{b}}$ & $\lambda_{\mathrm{P}}$ (failures $/ 10^{6} \mathrm{~h}$ ) \\
\hline $1 \mu \mathrm{F}$ & 40 & 0.34 & 2 & 10 & 0.029 & 0.197 \\
\hline
\end{tabular}

Table 5: The estimated base failure rate for the inductor.

\begin{tabular}{|c|c|c|c|c|c|c|c|}
$\mathrm{T}_{\mathrm{A}}\left({ }^{\circ} \mathrm{C}\right)$ & $\mathrm{T}_{\mathrm{HS}}\left({ }^{\circ} \mathrm{C}\right)$ & $\pi_{\mathrm{C}}$ & $\pi_{\mathrm{E}}$ & $\pi_{\mathrm{Q}}$ & $\lambda_{\mathrm{b}}$ & $\lambda_{\mathrm{P}}$ (failures $/ 10^{6} \mathrm{~h}$ ) \\
\hline
\end{tabular}

\begin{tabular}{l|l|l|l|l|l|l|l|}
\hline 40 & 69.32 & 1 & 4 & 20 & $6.22 \times 10^{-4}$ & 0.049 \\
\hline
\end{tabular}




\section{Conclusion}

A new approach to reliability assessment based on thermal analysis of the switch and diode was presented. The thermal analysis of a buck converter with the basic characteristics shown in Table 1 was conducted by calculating the temperature at the switch and diode junction. The total failure rate of the converter was expressed by summing the failure rate of the components using the parts count method. The procedure employed for the reliability analysis was that given in the MIL-HDBK-217F handbook. The results of the simulation using MATLAB Simulink showed that the buck converter analyzed will operate reliably for 3.8 years, which is an acceptable performance.

\section{References}

1. Huangfu Y, Ma R, Liang B, Li Y. "High power efficiency buck converter design for standalone wind generation system". International Journal of Antennas and Propagation, 1, 1-9, 2015. https:// doi.org/10.1155/2015/751830

2. Stupar A, Bortis D, Drofenik U, Kolar JW. "Advanced setup for thermal cycling of power modules following definable junction temperature profiles". Power Electronics Conference (IPEC), Sapporo, Japan, 21-24 June 2010. https://doi. org/10.1109/IPEC.2010.5542179

3. Zhang MT, Jovanovic M, Lee FC. "Design and analysis of thermal management for high-powerdensity converters in sealed enclosures". Applied Power Electronics Conference and Exposition, Atlanta, Georgia, 23-27 Feb 1997. https://doi. org/10.1109/APEC.1997.581482

4. Bašić $M$, Vukadinović $D$, Polić $M$. "Analysis of power converter losses in vector control system of a self-excited induction generator". Journal of Electrical Engineering, 65(2), 65-74, 2014. https:// doi.org/10.2478/jee-2014-0010

5. Usui M, Ishiko M. "Simple approach of heat dissipation design for inverter module". Proc. of International Power Electronics Conference (IPEC 2005), Niigata, Japan, 4-8 April 2005.

6. Lee TT, Mahalingam M. "Application of a CFD tool for system-level thermal simulation". IEEE Transactions on Components, Packaging, and Manufacturing Technology, Part A, 17(4), 564-572, 1994. https://doi.org/10.1109/95.335043

7. Lee $Y$, Hwang D. "A study on the techniques of estimating the probability of failure". Journal of Chungcheong Mathematical Society, 21(4), 573583, 2008.
8. Stapelberg RF. Handbook of reliability, availability, maintainability and safety in engineering design. $1^{\text {st }}$ ed. London, UK, Springer Science \& Business Media, 2009.

9. Ding Y, Loh PC, Tan KK, Wang P, Gao F. “Reliability Evaluation of Three-Level Inverters". Twenty-Fifth Annual IEEE Applied Power Electronics Conference and Exposition (APEC), Palm Springs, USA, 2125 February 2010. https://doi.org/10.1109/ APEC.2010.5433438

10. Alavi O, Hooshmand-Viki A, Shamlou S. "A comparative reliability study of three fundamental multilevel inverters using two different approaches". Electronics, 5(2), 1-18, 2016. https://doi.org/10.3390/electronics5020018

11. Dhople SV, Davoudi A, Domiínguez-Garciía $A D$, Chapman PL. "A unified approach to reliability assessment of multiphase DC-DC converters in photovoltaic energy conversion systems". IEEE Transaction on Power Electronics, 27(2), 739-751, 2012. https://doi.org/10.1109/ TPEL.2010.2103329

12. Arifujjaman M, Chang L. "Reliability comparison of power electronic converters used in gridconnected wind energy conversion system". 3rd IEEE International Symposium on Power Electronics for Distributed Generation Systems (PEDG), Aalborg, Denmark, 25-28 June 2012. https://doi. org/10.1109/PEDG.2012.6254021

13. Khosroshahi A, Abapour M, Sabahi M. "Reliability evaluation of conventional and interleaved DCDC boost converters". IEEE Transactions on Power Electronics, 30(10), 5821-5828, 2015. https://doi. org/10.1109/TPEL.2014.2380829

14. Rashidi-rad N, Rahmati A, Abrishamifar A. "Comparison of reliability in modular multilevel inverters". Przeglad Elektrotechniczny (Electrical Review), 88(1), 268-272, 2012.

15. Javadian V, Kaboli S. "Reliability assessment of some high side MOSFET drivers for buck converter". International Conference on Electric Power and Energy Conversion Systems, Istanbul, Turkey, 2-4October 2013. https://doi.org/10.1109/ EPECS.2013.6713092

16. Ranjbar AH, Abdi B, Gharehpetian GB, Fahimi B. "Reliability assessment of single-stage/twostage PFC converters". Compatibility and Power Electronics Conference, Badajoz, Spain, 20-22 May 2009. https://doi.org/10.1109/CPE.2009.5156043

17. Harb S, Balog RS. "Reliability of candidate photovoltaic module-integrated-inverter (PVMII) topologies-A usage model approach". IEEE Transactions on Power Electronics, 28(6), 3019-3027, 2013. https://doi.org/10.1109/ TPEL.2012.2222447 
18. Parvari R, Zarghani M, Kaboli S. "RCD snubber design based on reliability consideration: A case study for thermal balancing in power electronic converters". Microelectronics Reliability, 88, 1311-1315, 2018. https://doi.org/10.1016/j. microrel.2018.06.072

19. Ristow A, Begovic $M$, Pregelj A, Rohatgi A. "Development of a methodology for improving photovoltaic inverter reliability". IEEE Transactions on Industrial Electronics, 55(7), 2581-2592, 2008. https://doi.org/10.1109/TIE.2008.924017

20. Gupta N, Garg R, Kumar P. "Sensitivity and reliability models of a PV system connected to grid". Renewable and Sustainable Energy Reviews, 69, 188-196, 2017. https://doi.org/10.1016/j. rser.2016.11.031

21. Kadwane SG, Kumbhare JM, Gawande SP, Mohanta DK. "Reliability evaluation of BLDC drive in refrigeration systems". 42th Industrial Electronics Society Conference, 23 October, pp. 6645-6650, 2016. https://doi.org/10.1109/ IECON.2016.7793538

22. Memon HH, Alam MM. "Reliability, maintainability, availability and failure rate analysis of IGBT triggering system designed for marine environment". 13th International Bhurban Conference on Applied Sciences and Technology (IBCAST), 12 January, pp. 295-299, 2016. DOI: https://doi.org/10.1109/IBCAST.2016.7429893

23. Chen J. A Smart IGBT Gate Driver IC with Temperature Compensated Collector Current Sensing. PhD [dissertation]. University of Toronto, 2018.

24. Wang H, Ma K, Blaabjerg F. "Design for reliability of power electronic systems". 38th Annual Conference on IEEE Industrial Electronics Society, Montreal, Canada, 25-28 October 2012. https:// doi.org/10.1109/IECON.2012.6388833

25. Richardeau F, Pham TT. "Reliability calculation of multilevel converters: Theory and applications". IEEE Transactions on Industrial Electronics, 60(10), 4225-4233, 2013. https://doi.org/10.1109/ TIE.2012.2211315

26. Lyu MR. Handbook of software reliability engineering. $1^{\text {st }}$ ed. New York, NY, USA, IEEE computer society press, 1996.

27. Denson WA. "Tutorial: PRISM". RAC Journal, 1-6, 1999.

28. Telcordia Technologies. "Special Report SR-332: Reliability Prediction Procedure for Electronic Equipment (Issue 1)". Telcordia Customer Service, Piscataway, USA, 2001

29. SAE G-11 Committee. "Aerospace Information Report on Reliability Prediction Methodologies for Electronic Equipment AIR5286". Draft Report, 1998.
30. Union Technique de L'Electricité. “Recueil de données des fiabilite: RDF 2000. Modèle universel pour le calcul de la fiabilité prévisionnelle des composants, cartes et équipements électroniques". 2000.

31. Siemens AG. "Siemens Company Standard SN29500 (Version 6.0). Failure Rates of Electronic Components". Siemens Technical Liaison and Standardization, 1999.

32. British Telecom. "Handbook of Reliability Data for Components Used in Telecommunication Systems". London, UK, 1987.

33. Pecht MG, Nash FR. "Predicting the reliability of electronic equipment [and prolog]". Proceedings of the IEEE, 82(7), 992-1004, 1994. https://doi. org/10.1109/5.293157

34. "MIL-HDBK-217F (Notice 2). Military handbook: Reliability prediction of electronic equipment". Department of Defense, USA, 1995.

35. Abdi B, Ranjbar AH, Gharehpetian GB, Milimonfared J. "Reliability considerations for parallel performance of semiconductor switches in high-power switching power supplies". IEEE Transactions on Industrial Electronics, 56(6), 2133-2139, 2009. https://doi.org/10.1109/ TIE.2009.2014306

36. Rausand M, Hoyland A. System reliability theory: Models, statistical methods, and applications. $2^{\text {nd }}$ ed. New York, NY, USA, Wiley, 2004.

37. Aten M, Towers G, Whitley C, Wheeler P, Clare J, Bradley K. "Reliability comparison of matrix and other converter topologies". IEEE Transactions on Aerospace and Electronic systems, 42(3), 2006. https://doi.org/10.1109/TAES.2006.248190

38. Chen G, Burgos R, Liang Z, Lacaux F, Wang F, Van Wyk JD, Odendaal WG, Boroyevich D. "Reliabilityoriented design considerations for high-power converter modules". 35th Annual Power Electronics Specialists Conference, pp. 419-425, 2004. https:// doi.org/10.1109/PESC.2004.1355782

39. Walters K. Rectifier Reverse Switching Performance, Microsemi, 1998.

40. Chan F, Calleja H. "Reliability estimation of three single-phase topologies in grid-connected PV systems". IEEE Transactions on Industrial Electronics, 58(7), 2683-2689, 2011. https://doi.org/10.1109/ TIE.2010.2060459

41. Ma K, He N, Liserre M, Blaabjerg F. "Frequencydomain thermal modeling and characterization of power semiconductor devices". IEEE Transactions on Power Electronics, 31(10), 7183-7193, 2016.

42. Pandya $\mathrm{KL}, \mathrm{McD}$ aniel W. "A simplified method of generating thermal models for power MOSFETs". 18th Annual Symposium on Semiconductor Thermal Measurement and Management, pp. 83-87, 2002. https://doi.org/10.1109/STHERM.2002.991350 
43. Ram SS, Vijayakumari A. "Thermal modeling of wide bandgap semiconductor devices for high frequency powerconverters".IOPConferenceSeries: Materials Science and Engineering, 2018. https:// doi.org/10.1088/1757-899X/310/1/012133

44. Fraisse G, Souyri $B$, Pinard $S$, Ménézo C. "Identification of equivalent thermal RC network models based on step response and genetic algorithms". 12th Conference of International Building Performance Simulation Association, Sydney, 2011.

45. Chen TY, Kuo SL, Hsu JM, Pan CW. "Dynamic compact thermal modeling of packageon-package by thermal resistor-capacitor ladder". 15th Conference on Thermal and Thermomechanical Phenomena in Electronic Systems (ITherm), pp. 223-229, 2016. https://doi. org/10.1109/ITHERM.2016.7517554

46. Stout R. "How to Use Thermal Data Found in Data Sheets. ON Semiconductor Application Note AND8220", ON Semiconductor Products Inc., Phoenix: Arizona, 2006.

47. Schonberger J. "Thermal Simulation of a Buck Converter". Plexim GmbH, 2010.

48. Graovac D, Purschel M. "IGBT Power losses calculation using the data-sheet parameters". Infineon Application Note, Neubiberg, Germany, 2009.

49. Fuji Electric Device Technol. Co. Ltd. "Fuji 2MBI150U2A-060 600V/150A IGBT module datasheet". Fuji IGBT Modules Application Manual. Application Note, Feb 2004.

50. Ma K, Munoz-Aguilar RS, Rodriguez P, Blaabjerg F. "Thermal and efficiency analysis of fivelevel multilevel-clamped multilevel converter considering grid codes". IEEE Transactions on Industry Applications, 50(1), 415-423, 2014. https://doi.org/10.1109/TIA.2013.2266391

Arrived: 27. 01. 2018

Accepted: 23. 11. 2018 